\title{
Leksykalna analiza zrozumiałości tekstów medycznych na podstawie opisów badań obrazowych i wypisów ze szpitala
}

Lexical analysis of readability of medical texts:

the case of image reports and hospital discharge summaries

\author{
Anna BĄCZKOWSKA ${ }^{1}$ \\ Uniwersytet Gdański
}

Ewa KOŚCIAŁKOWSKA-OKOŃSKA²

Uniwersytet Mikołaja Kopernika w Toruniu

\begin{abstract}
Streszczenie dyskursu medycznego. obrazowych, przekład tekstów medycznych

1 https://orcid.org/0000-0002-0147-2718

Uniwersytet Gdański

anna.k.baczkowska@gmail.com

2 https://orcid.org/0000-0001-5232-1373

Uniwersytet Mikołaja Kopernika w Toruniu

ewako@umk.pl
\end{abstract}

Artykuł przedstawia analizę cech leksykalnych dwóch typów tekstów medycznych: wypisów ze szpitali i opisów badań obrazowych. Celem analizy jest ocena stopnia zrozumiałości (tj. czytelności) ww. tekstów medycznych oraz jej znaczenia w procesie przekładu. Z przeprowadzonego badania pilotażowego wynika, że wypisy ze szpitala, wbrew założeniom, okazały się być nieznacznie trudniejsze w odbiorze dla przeciętnego czytelnika (pacjenta) niż opisy badań obrazowych. W analizie zauważono też pewne problemy metodologiczne, które powinny być uwzględnione w korpusowych badaniach czytelności, zwłaszcza w przypadku

Słowa kluczowe: czytelność, korpus, dyskurs medyczny, wypisy ze szpitala, opisy badań 
Abstract

This article presents a lexical analysis of two types of medical texts written in Polish: hospital discharge summaries and image reports. The aim of the analysis is to assess the readability of the medical texts under investigation and its importance in the process of translation. It was assumed that the language of discharge summaries should be relatively comprehensible for a layman (patient), so that he or she could understand the description of the diagnosis and follow the instructions provided by doctors regarding post-hospital measures (such as adherence to medication regime and recommended further medical examinations). Image reports are written by experts for experts, so it can be expected that the language used in image reports is highly specialized and barely comprehensible for a patient. The pilot study has demonstrated that the discharge summaries, contrary to our assumptions, turned out to be slightly less readable for an average reader (patient) than the image reports.

Keywords: readability, corpus, medical discourse, hospital discharge summaries, image reports, translation of medical texts

\section{Wstęp}

Podstawowym celem języka tekstów medycznych jest komunikacja; przebiega ona zarówno na płaszczyźnie profesjonalnej (np. na podstawie opisów badań obrazowych, gdzie mamy do czynienia z komunikacją lekarz-lekarz / ekspertekspert / specjalista-specjalista), oraz na płaszczyźnie, którą możemy nazwać codzienną (np. wypisy ze szpitala, obrazujące komunikację między lekarzem a pacjentem). Ponieważ teksty siłą rzeczy są zróżnicowane ze względu na ich odbiorców (specjalista vs. niespecjalista), dla tłumacza zajmującego się ich przekładem istotne jest znalezienie efektywnego sposobu komunikacji z odbiorcami przy uwzględnieniu ich oczekiwań, potrzeb, wymagań, ale także szeroko pojętych kompetencji. Przed tłumaczem stoi zatem nie tylko mierzenie się $\mathrm{z}$ trudnościami związanymi $\mathrm{z}$ tekstem per se (np. terminologią, wiedzą specjalistyczną etc.), ale także $\mathrm{z}$ komunikacyjną skutecznością takiego przekładu, czyli właściwym zrozumieniem tekstu przez odbiorcę. Aby odbiorca tekst zrozumiał, musi on być czytelny, czyli w podstawowym rozumieniu tego pojęcia napisany $\mathrm{w}$ sposób jasny $\mathrm{i}$ zrozumiały. W tym miejscu można powtórzyć za Pieńkosem (2003, s. 275), że czytelność jest jedną z najistotniejszych zalet przekładu tekstów naukowych lub technicznych (a takimi tekstami są bez wątpienia teksty medyczne).

Kwestia czytelności została - w kontekście przekładu tekstów medycznych - dosyć szeroko opracowana przez ustawodawcę w odniesieniu na przykład do ulotek lekowych, ponieważ efektywność przekazu treści zależy tu od zdolności czytania i rozumienia tekstów pisanych jej odbiorców. Z tej 
przyczyny ulotka, przed zatwierdzeniem przez Urząd Rejestracji Produktów Leczniczych, Wyrobów Medycznych i Produktów Biobójczych, musi przejść tzw. badanie czytelności, zgodnie z rozporządzeniem Ministra Zdrowia z dnia 26 kwietnia 2010 r. w sprawie badania czytelności ulotki (zob. KościałkowskaOkońska, 2017). To jedyny w zasadzie rodzaj tekstów medycznych, w którym potrzeba czytelności została ustawowo podkreślona i wyeksplikowana. Niewątpliwie warto byłoby również podjąć próbę pewnej ramifikacji tekstów medycznych w kontekście ich czytelności w ogóle, w tym będących celem analizy $\mathrm{w}$ niniejszym artykule wypisów szpitalnych oraz wyników badań obrazowych.

Spojrzenie na czytelność nie tylko z perspektywy językoznawczej, ale również przekładoznawczej może stanowić interesujący przyczynek do stworzenia nowej przestrzeni badawczej. Należy zaznaczyć, że same badania nad czytelnością w przekładzie są relatywnie niezbyt częste, ale można rozpatrywać je dwojako: z jednej strony mają na celu poprawienie tłumaczenia poprzez zastosowanie wskaźnika i kryteriów czytelności, z drugiej zaś służą porównaniu tekstu źródłowego $\mathrm{z}$ tekstem docelowym. Związek pomiędzy problemami w przekładzie a czytelnością omawiają na przykład Wang, Miller, Schmidt i Wen (2012), którzy twierdzą, że może ona być wskazówką dla tłumaczy przy dokonywaniu wyboru strategii tłumaczeniowych czy stylu tekstu.

W kontekście przekładu można rzecz jasna zastanowić się, jakie znaczenie ma czytelność dla ekwiwalencji tłumaczeniowej; w klasycznym ujęciu Toury'ego (1995) adekwatność i akceptowalność przekładu są kluczowe. Warto natomiast zauważyć, że czytelność w kontekście przekładu tekstów medycznych ma znaczenie priorytetowe: tekst ekwiwalentny, co rozumiemy jako tekst adekwatnie przekazujący treść i funkcję tekstu źródłowego, jest tekstem akceptowalnym dla odbiorcy docelowego, ale przede wszystkim musi on być czytelny. A zatem czytelność stanowi warunek sine qua non adekwatności i akceptowalności tłumaczenia, a tym samym realizuje cel komunikacyjny, jakim jest przekazanie treści odbiorcy.

\section{Czytelność a spójność tekstu}

Poziom trudności tekstu bywa określany $\mathrm{w}$ wieloraki sposób. Jedna z prostszych i popularniejszych definicji czytelności tekstu (ang. readability) określa ją jako cechy tekstu pozwalające na jego bezwysiłkowe czytanie i rozumienie (Nielsen-Bohlman, Panzer, Kinding 2004, Bailin, Grafstein 2016: 
177). Zwykle określa się dolny pułap poziomu edukacji potencjalnego czytelnika, dla którego dany tekst ma być zrozumiały w sposób bezwysiłkowy. W Polsce nie określono takiego poziomu granicznego, w przeciwieństwie na przykład do USA, gdzie za minimalny etap wykształcenia przyjęto szóstą klasę szkoły podstawowej (USDDH 2010).

Definiując czytelność, należy odróżnić angielskie słowo legibility od readability. Oba terminy mogą być przetłumaczone na język polski jako czytelność, jednak legibility dotyczy technicznych aspektów tekstu (typograficznych) pozwalających na jego prawidłowe odczytanie, np. wielkości, koloru i typu czcionki, układu tekstu na stronie, możliwości odczytania pisma odręcznego itp., natomiast readability odwołuje się do parametrów lingwistycznych i jego znaczenia i/lub stopnia zrozumienia tekstu przez czytelnika (zob. Wolfer 2015: 34-37).

Oprócz terminu czytelność (Pisarek 2007) można się też spotkać z wieloma innymi, np. zrozumiałość tekstu (comprehensibility, Garner, Ning, Francis, 2012, Pisarek 2007, Gruszczyński, Ogrodniczuk 2015, Zarzeczny, Piekot 2017: 10), niezrozumiałość (Gruszczyński, Ogrodniczuk 2015), trudność (Broda i in. 2010, Gruszczyński, Ogrodniczuk 2015), łatwość (easibility McNamara i in. 2014), przystępność i prostota języka (Zarzeczny, Piekot 2017), a także klarowność, jasność czy dostępność (Charzyńska i in. 2015). W niniejszym artykule określenia te będą używane wymiennie.

Wyżej wymienione pojęcia nie są jednak równoważne. Dla przykładu łatwość rozumiana jest szeroko i dotyczy parametrów tekstu wynikających zwłaszcza z analizy warstwy leksykalnej, syntaktycznej i stylistycznej (McNamara i in. 2014: 84). Podobnie czytelność definiują Allan Bailin i Ann Grafstein (2016: 2), dla których jest to pojęcie odwołujące się do składni, semantyki, morfologii i cech dyskursu. Mark Garner, Zhenye Ning i Jill Francis (2012) natomiast oddzielają pojęcie czytelności, które przypisują cechom tekstu, od pojęcia zrozumiałości, które ma ściśły związek ze zdolnościami poznawczymi czytelnika umożliwiającymi mu rozumienie tekstu. Dla psychologa George’a Klare'go (1963, rozdz. I) czytelność związana jest przede wszystkim z czytelnikiem (np. umiejętnością i szybkością czytania, zdolnością zapamiętywania itp.), a nie $\mathrm{z}$ parametrami tekstu. Ocena klarowności tekstu przez czytelnika jest u niego kluczowym elementem definicji czytelności, bowiem według tego badacza bez istnienia czytelnika, dla którego tekst jest możliwy do zrozumienia, nie można w ogóle mówić o jego czytelności, nawet jeśli testy szacujące przystępność języka na podstawie formuł czytelności określają dany tekst jako zrozumiały. Innymi słowy, według Klare’go warunkiem koniecznym oceny czytelności tekstu jest istnienie jego czytelnika. 
Podobne psycholingwistyczne aspekty czytelności porusza Sascha Wolfer (2015), który termin comprehensibility (zrozumiałość) kontrastuje z terminem comprehension (zrozumienie). Proces rozumienia tekstu przez czytelnika dzięki konstruowaniu przez niego reprezentacji mentalnych to dla Wolfera comprehension, natomiast stopień łatwości zrozumienia tekstu to comprehensibility (Wolfer 2015: 34). Danielle McNamara i in. (2014) używają zbliżonej terminologii, bowiem przez text comprehension easability rozumieją stopień zrozumiałości tekstu przez potencjalnego czytelnika, natomiast aspekty związane z cechami tekstu nazywają text complexity (złożonością tekstu) albo cohesion (spójnością).

Już na podstawie tych kilku przytoczonych powyżej definicji widać wyraźnie, że dyskusja dotycząca pojęcia czytelności toczy się pomiędzy dwoma biegunami: albo jest zorientowana na tekst i jego parametry leksykalnosyntaktyczno-stylistyczne, albo na czytelnika i jego zdolności poznawcze. Ta dychotomia pojęciowa nie zawsze jest jednak binarna i wykluczająca się; te dwie orientacje częściej postrzegane są jako aspekty przenikające się i dopełniające. Badania pokazują, że istnieje znacząca korelacja między wynikami testów na ocenę złożoności tekstu i tych dotyczących procesów jego rozumienia (McNamara i in. 2014: 13), tj. teksty, które są łatwe do zrozumienia, zawierają na przykład dużą liczbę słów o wysokiej frekwencji i stosunkowo krótkie zdania.

Według niektórych autorów anglojęzycznych (McNamara i in. 2014: 18-39, Bailin, Grafstein 2016: 177), czytelność zdeterminowana jest w dużej mierze przez spójność tekstu. Generalnie rzecz biorąc, spójność w językoznawstwie rozumiana jest dwojako, albo jako cecha „globalna” tekstu, co w języku angielskim określa się coherence (koherencja), albo jako jego cecha „lokalna”, znana w literaturze anglojęzycznej jako cohesion (kohezja). Koherencja tworzy spójność logiczną całego tekstu, zależy od kontekstu ${ }^{3}$ i interpretacji czytelnika, kohezja natomiast polega na połączeniu poszczególnych fragmentów tekstu w spójną całość (Bublitz 2011). Na przykład można łączyć wyrazy w zdania za pomocą wykładników relacji syntaktycznych (konektorów ${ }^{4}$ dlatego, o ile itp.), zdania czy paragrafy za pomocą operatorów

\footnotetext{
${ }^{3}$ Przez kontekst rozumiemy tutaj konkretnie konsytuację i kotekst (więcej o różnicy pomiędzy kontekstem, konsytuacją i kotekstem zob. Boniecka 1994).

${ }^{4}$ Konektory to termin używany przez Jerzego Bartmińskiego i Stanisławę NiebrzegowskąBartmińską (2009) dla określenia wyrazów typu dlatego, o ile itp. Dla Stanisława Gajdy (1982: 135) z kolei są to przykłady konektywów, a konkretnie spójników pierwotnych i wtórnych oraz tranzycji (np. z kolei, z drugiej strony itp.), bowiem pojęcie konektorów u Gajdy zarezerwowane
} 
wewnątrztekstowych (jak międzyzdaniowe lub międzyakapitowe wykładniki segmentacji, sygnałów porządku logicznego, następstwa itp. typu jak wynika z powyższego, w związku z tym, z tego powodu, podsumowując, przejdę teraz do, przy okazji, jeśli chodzi o), a także poprzez użycie anafory ${ }^{5}$. Pojęcie koherencji wydaje się zatem bliskie pojęciu czytelności zorientowanej na czytelnika, natomiast termin kohezja jest pochodną czytelności zorientowanej na tekst.

$\mathrm{Na}$ marginesie warto wspomnieć, gwoli uściślenia definicji, że w językoznawstwie polonistycznym używa się też określeń spójność linearna (dla określenia angielskiego terminu cohesion) i spójność semantyczna (dla określenia angielskiego terminu coherence) (Dobrzyńska 2009: 20). Znane są też określenia spoistość czy spójność powierzchniowa, tj. angielskie cohesion, oraz spójność pojęciowa, tj. angielskie coherence (Bartmiński, NiebrzegowskaBartmińska 2009). Autorzy Jasnopisu z kolei używają terminów spójność tematyczna lub treściowa dla określenia koherencji i spójność formalna lub znaczeniowa w wypadku kohezji (Gruszczyński, Hadryan 2015: 43).

Wróćmy do pojęcia spójności. Otóż możliwa jest sytuacja, w której tekst jest koherentny, tj. zawiera wiele fraz łączących i odwołań do wcześniej użytych wyrazów (jest zatem spójny linearnie), jednak jako całość nie jest spójny (semantycznie); jak również sytuacja odwrotna, w której brak łączników zdań (np. w takim razie, jak wynika itp.) oraz odniesień anaforycznych, jednak mimo to tekst (również krótki, np. sekwencja dwóch zdań) wydaje się spójny, tj. logicznie powiązany (van Dijk 2008: 45-49). Na pojęcie spójności trzeba zatem spojrzeć całościowo, uwzględniwszy zarówno kohezję, jak i koherencję. Kohezja jednak, choć nie jest elementem niezbędnym, jest zwykle warunkiem koherencji (Bublitz 2011: 42). Kohezja lub koherencja między poszczególnymi zdaniami to bardzo ważne czynniki sprzyjające czytelności (por. np. Halliday, Hasan 1976, McNamara i in. 1996).

McNamara i in. (2014: 1-2, 11, 56) definiują w swoich badaniach pojęcia kohezji i koherencji w następujący sposób. Przez kohezję rozumieją cechy tekstu świadczące o jego spójności na poziomie konceptualnym, a więc elementy wiążące i wyjaśniające zdarzenia, osoby, cele itd. Koherencja zaś miałaby być konsekwencjami kohezji, które powstają w umyśle czytelnika, tj. spójnością reprezentacji mentalnych, które czytelnik może skonstruować (liczbą skojarzeń

są dla zaimków względnych (np. który), które są podgrupą konektywów. W języku angielskim używa się najczęściej określenia discourse markers.

5 Więcej na temat spójności wewnątrztekstowej zob. Bartmiński, Niebrzegowska-Barmińska 2012: 282-292. 
i połączeń między reprezentacjami). Spójność w projekcie McNamary i in. (2014) utożsamiana jest przede wszystkim z kohezją, jednak pojęcie to, bardzo rozbudowane i analizowane na pięciu poziomach dotyczących użycia leksyki, składni, relacji wewnątrztekstowych, modelu sytuacyjnego oraz struktury retorycznej i gatunku, nie jest ściśle oddzielone od koherencji. Spójność badana jest na przykład poprzez analizę okurencji różnych części mowy czy różnych typów czasowników (kauzatywnych i wyrażających intencję), liczbę wyrazów w prepozycji do frazy nominalnej, gęstość leksykalną i wystąpienia negacji, podobieństwa semantyczne między słowami, zdaniami i paragrafami (i inne dane psycholingwistyczne) itp. (McNamara i in. 2014). Pojęcie spójności, które utożsamiane jest z czytelnością, jest szerokie, a dychotomia kohezja-koherencja opisywana przez wyżej wymienionych autorów wydaje się być pozorna, bowiem jej elementy są ściśle ze sobą związane. Nawiązując do wcześniejszych rozstrzygnięć definicyjnych, kohezja zespolona jest ze złożonością tekstu (McNamara i in. 2014) czy jego zrozumiałością (comprehensibility, Wolfer 2015), natomiast koherencja jest bliższa koncepcji zrozumienia (comprehension, Wolfer 2015).

Jedni z nielicznych badaczy czytelności w języku polskim, współautorzy książki Jasnopis i aplikacji o takiej nazwie, na której opiera się część badań przedstawionych $\mathrm{w}$ dalszej części artykułu, spójność uważają za cechę przecenianą i w związku $\mathrm{z}$ tym deklarują, że nie uwzględnia jej Jasnopis (Gruszczyński, Hadryan 2015: 44). Utożsamiają oni jednak pojęcie spójności z użyciem spójników i zaimków anaforycznych (Gruszczyński, Hadryan 2015: 44), czyli zasadniczo z niektórymi przejawami kohezji. Michael Halliday i Ruqaiya Hasan (1976) w książce pt. Cohesion in English analizują jednak aż pięć typów kohezji (które nazywają ties): referencję, substytucję, spójnik, elipsę i kohezję leksykalną. Jak wynika z powyższej dyskusji, spójności nie definiuje się w literaturze anglojęzycznej jedynie jako używania spójników i anafory, ale odsyła ona do całej gamy innych sposobów tworzenia w tekście kohezji oraz spójności logicznej (zob. np. Halliday, Hasan 1976, McNamara i in. 2014, Bailin, Grafstein 2016). Spójność rozumiana jest zatem przez twórców Jasnopisu w wąskim sensie, w znaczeniu odnoszącym się do niektórych typów kohezji, natomiast przez np. Hallidaya i Hasana (1976) czy McNamarę i in. (2014) - jako znacznie szersze pojęcie. Niniejsze badanie ograniczone jest narzędziami dostępnymi w aplikacji Jasnopis, zatem pewne elementy mierzące spójność $\mathrm{z}$ konieczności nie zostaną uwzględnione. 


\section{Badania nad czytelnością tekstów medycznych}

Badania nad czytelnością tekstów medycznych nie są zagadnieniem zupełnie nowym. Autorzy wielu artykułów naukowych podejmują się analizy zrozumiałości różnego rodzaju tekstów medycznych, por. np. Perbinder Grewal, Swethan Alagaratnam 2013, Grace Huang i in. 2015, Thomas Dobbs i in. 2017. Są to jednak opracowania głównie badaczy anglojęzycznych, w Polsce natomiast tematyka ta jest nowa i podejmowana przez nielicznych badaczy, por. np. Mamet 2002, Bączkowska 2019, Bączkowska 2020a, Bączkowska 2020 b. Ponadto badania anglojęzyczne prowadzone są zasadniczo nie przez językoznawców, lecz lekarzy o różnych specjalnościach.

W opracowaniach tych (np. Osborne 2004) często wymieniane są takie testy czytelności jak Simplified Measure of Gobbledygook (SMOG), the Fry Readability Scale (FRY) czy też Flesch-Kincaid Grade Level (FKGL). Część z nich powstała przynajmniej kilka dekad temu i ocenia stopień złożoności tekstu głównie na podstawie długości zdań i słów, tymczasem bliższe nam czasowo badania (np. Kandula, Zeng-Treitler 2008) zwracają uwagę na ograniczenia tych testów.

Ograniczenia te wynikają z faktu, że zdecydowana większość publikacji anglojęzycznych dotyczących czytelności języka medycznego (autorstwa specjalistów z medycyny) to opracowania oparte na tzw. klasycznych testach na czytelność, które doczekały się już wielu głosów krytycznych (por. np. Davidson, Kantor 1982, Clerehan, Buchbinder, Moodie 2005, Garner, Ning, Francis 2012, McNamara i in. 2014, Gruszczyński, Ogrodniczuk 2015, Bailin, Grafstein 2016, Bączkowska 2019, Bączkowska 2020a). Problem z tymi testami polega na tym, że zrozumiałości tekstu nie można mierzyć jedynie w sposób mechaniczny, przez szacowanie liczby sylab czy liter w wyrazie oraz liczby wyrazów w zdaniu, bowiem niektóre wyrazy krótkie są trudne do zrozumienia (np. apnoea, krwistek), a inne są łatwe, mimo iż są wielosylabowe (np. informacja, krótkowzroczność). Z tego względu rosnące grono autorów (głównie językoznawców i psychologów) mierzy czytelność nie tylko za pomocą testów klasycznych (lub nawet w ogóle bez ich uwzględnienia), ale też stosując indeksy leksykalne, gramatyczne i stylistyczne tekstów (m.in. Gruszczyński, Ogrodniczuk 2015, Bailin, Grafstein 2016, Crossley, Kyle, McNamara 2016, Crossley, Skalicky, Dascalu 2019, Bączkowska 2019, Bączkowska 2020a, Bączkowska 2020b). Niniejsze badanie ilustruje nowe (tj. nieklasyczne) podejście do czytelności, gdzie złożoność tekstu mierzy się przede wszystkim indeksami leksykalnymi. 
Kandula i Zeng-Treitler (2008) zauważają ponadto, że większość badań nad czytelnością skupia się na samym tekście, tymczasem znaczenie ma również organizacja treści, układ i projekt tekstu. Do oceny czytelności całego materiału tekstowego służy np. Suitability Assessment of Materials (SAM) opracowane przez Doak, Doak i Root (1996). Innym z kolei testem jest PMOSE/KIRSCH stworzony przez Mosenthal i Kirsch (1998), który mierzy czytelność tabel i wykresów (oba te narzędzia są dosyć skomplikowane i nie można ich stosować $\mathrm{w}$ komputerowej analizie, co obecnie $\mathrm{z}$ pewnością ogranicza ich wykorzystanie).

\section{Materiał}

Analizowane dokumenty (wypisy szpitalne oraz wyniki badań obrazowych) pochodzą $\mathrm{z}$ zasobów tłumaczeniowych jednej $\mathrm{z}$ autorek (E. K.-O.); z materiałów do analizy zostały usunięte wszystkie dane wrażliwe. Stanowią one przykład tekstów skonwencjonalizowanych (por. Wojtak 2005), czyli na poziomie struktury są niezbyt elastyczne oraz mają ustalony porządek występowania pewnych elementów. Na poziomie pragmatycznym ich celem jest osiągnięcie określonego celu komunikacyjnego (wspomniana już komunikacja lekarz-lekarz lub lekarz-pacjent) typowego dla danego tekstu. Z punktu widzenia stylistycznego występują $\mathrm{w}$ nich charakterystyczne związki frazeologiczne, terminologia o wysokim stopniu złożoności i specjalizacji inherentna dla tekstów medycznych (w tym wyrazy pochodzenia łacińskiego) oraz ustalony uzusem wzorzec projektowania i sporządzania tekstu. Tym samym użycie w przekładzie takiego tekstu związku czy zwrotu różniącego się od tych zazwyczaj stosowanych może stanowić nieoczekiwany, zaskakujący element czy nawet przeszkodę w zrozumieniu komunikatu w sposób właściwy.

Trudności $\mathrm{w}$ tłumaczeniu tekstów skonwencjonalizowanych mogą wystąpić na różnych poziomach organizacyjnych. Wydawałoby się, że $\mathrm{w}$ ramach obiegu naukowego w świecie zachodnim (myślimy tu np. o krajach UE, Stanach Zjednoczonych, Kanadzie, Australii czy innych krajach anglojęzycznych znajdujących się pod kulturowym wpływem wyżej wymienionych) gatunki o podobnych nazwach/funkcjach będą miały podobny układ strukturalny i treściowy oraz będą pełniły tę samą funkcję. Często jednak analizy porównawcze pokazują, że trudno mówić o wielopoziomowej ekwiwalencji tych tekstów ( $w$ tym na poziomie tekstowym) - problemy tłumaczeniowe mogą być również rezultatem istnienia i funkcjonowania gatunków tekstowych w różnych społecznościach (językowych czy 
kulturowych; widać to wyraźnie między innymi na przykładzie różnic struktury i treści ulotek dla pacjenta w układzie językowym polski-angielski, zob. Kościałkowska-Okońska, 2019).

Gatunki tekstów nie funkcjonują oczywiście w próżni, ale w kontekście, zachodzi pomiędzy nimi interakcja, nakładanie się na siebie, a tym samym trudno jest dokonać ich precyzyjnego podziału. Tworzą raczej koncepty, które Bhatia (2002) nazywa „koloniami gatunków” (ang. genre colonies), a Bazerman (1994) „systemami gatunków” (ang. genre systems), wzajemnie ze sobą powiązane i interaktywne w konkretnych układach (Bazerman 1994: 97), a zatem występowanie (lub brak) jakiegoś gatunku pociąga za sobą konsekwencje dotykające całości jakiejś rzeczywistości tekstowej właśnie z uwagi na te wzajemnie powiązania.

W przypadku tekstów medycznych wspomniana przez Bhatię „kolonia gatunków" składałaby się z różnych przykładów istniejących i zdefiniowanych gatunków. Próby ich określenia podjęli się Montalt i Gonzalez Davies (2007), którzy wyróżnili kilkanaście gatunków w zależności od celu, jakiemu służą (choć granice pomiędzy tymi celami są nieco płynne, co zresztą potwierdza ustalenie Bhatii). Są to na przykład ulotki i materiały informacyjne dla pacjenta, formularze świadomej zgody, raporty z badań, protokoły badań klinicznych czy wytyczne dotyczące badań klinicznych (Monalt, Gonzalez Davies, 2007, s. 57-89). Interesujące nas wyniki badań oraz wypisy szpitalne znalazły się w kategorii gatunków definiowanych ze względu na pełnione przez nie funkcje społeczne, czyli w tym przypadku komunikowanie treści odbiorcy, który nie jest specjalistą, oraz sprawozdanie z realizacji praktyki klinicznej w odniesieniu do jednostki.

Gatunki tekstów medycznych służą wspomnianej już na początku komunikacji lekarz-lekarz i lekarz-pacjent (Montalt i Gonzalez Davies nazywają je „mostami komunikacyjnymi”; kwestia komunikacji w tekstach medycznych została również omówiona przez Ezpeleta-Piorno, 2012, a analizy porównawcze dotyczące różnych gatunków tekstów medycznych można znaleźć w pracy Gonzalez Darriba, 2018). W badaniach grupy GENTT (zob. Gonzalez Darriba, 2018) pojawiła się propozycja podziału gatunków tekstów medycznych na sześć kategorii: 1) kliniczne; 2) informacyjne, 3) metagatunkowe; 4) edukacyjne; 5) promocyjne oraz 6) naukowe. W świetle takiego podziału można zaliczyć wypisy szpitalne i wyniki badań obrazowych do pierwszej kategorii gatunków klinicznych.

Należy podkreślić, że wypisy szpitalne i wyniki badań nie znajdowały się do tej pory $\mathrm{w}$ spektrum zainteresowania badaczy. Ich cechami 
charakterystycznymi są niewątpliwie precyzja, zwartość oraz styl narracji, duży udział strony biernej, jednostki leksykalne w postaci terminologii fachowej, stosowanie czasu przeszłego oraz równoważników zdań.

\section{Metodologia}

Niniejsze badanie koncentruje się jedynie na cechach tekstu, czyli implementuje metodę analityczną, a zatem nie uwzględnia aspektów psycholingwistycznych sprawdzających interakcję zachodzącą między tekstem a czytelnikiem (bada złożoność tekstu, a nie jego rozumienie przez czytelnikapacjenta, gotowość czytelnika do przeczytania tekstu, jego zainteresowanie tematem itp.).

Dla potrzeb analizy utworzono dwa korpusy danych: korpus opisów badań obrazowych (KBO) i korpus wypisów ze szpitala (KWS). KBO zawiera 993 słowa, a KWS składa się z 1874 słów. W sumie cały materiał korpusowy liczy 2867 słów. Dane analizowano według następujących 14 indeksów: procent wyrazów trudnych, indeks mglistości, indeks Pisarka, słowa rzadkie (hasłowe), procent wyrazów rzadkich, procent rzeczowników i czasowników wraz $\mathrm{z}$ ich logarytmami, procent rzeczowników trudnych, procent czasowników trudnych, procent przymiotników, procent przymiotników trudnych, procent rzeczowników w stosunku do czasowników, gerundia oraz rzeczowniki abstrakcyjne. Dodatkowo uwzględniono wskaźniki pomocnicze zapożyczone z klasycznych testów na czytelność: liczbę sylab w wyrazie, liczbę wyrazów w zdaniu i liczbę słów w tekście.

Do obliczenia powyższych parametrów użyto metod i narzędzi $\mathrm{z}$ zakresu przetwarzania języka naturalnego dostępnych $\mathrm{w}$ komercyjnych wersjach dwóch programów komputerowych: Jasnopisu (jasnopis.pl) oraz systemu Sketch Engine (dalej: SK; sketchengine.eu). Jasnopis to stosunkowo nowe (udostępnione w 2015 r.) i jeszcze mało znane narzędzie automatyzujące obliczenia służące analizie czytelności tekstów w języku polskim. Jest to aplikacja internetowa dostępna bez opłat w wersji demonstracyjnej (ma jednak ograniczenia co do długości tekstu). Aplikacja ta analizuje kilka parametrów leksykalnych oraz wykładników dotyczących długości wyrazów i zdań typowych dla klasycznych testów czytelności; zawiera również predyktor potencjalnego zrozumienia tekstu przez czytelnika określony jako klasa trudności tekstu. Powstała ona w efekcie interesującego projektu, który oprócz wskaźników leksykalnych włączał do analizy czytelności również badania psycholingwistyczne, mierzące zarówno obiektywne cechy respondentów 
(wykształcenie, wiek itp.), jak i ich subiektywne oceny tekstu, a także takie cechy respondentów jak na przykład motywacja do przeczytania tekstu czy zainteresowanie jego tematyką. Wyniki tych badań psycholingwistycznych zostały zaimplementowane do aplikacji Jasnopis w taki sposób, aby mogła ona określać przewidywaną klasę trudności tekstu. Tym samym twórcy tej aplikacji odchodzą od określania czytelności w oparciu jedynie o wskaźniki używane w testach klasycznych (liczba liter, sylab i wyrazów) i proponują połączenie analizy złożoności tekstu z jego zrozumiałością.

Uznając istotny wkład twórców Jasnopisu w rozwój badań nad czytelnością tekstów użytkowych pisanych w języku polskim, należy jednak zauważyć, że w porównaniu $\mathrm{z}$ dostępnymi programami i aplikacjami analizującymi teksty $\mathrm{w}$ języku angielskim aplikacja ta ma pewne ograniczenia. Wadą Jasnopisu jest mała liczba parametrów obliczanych przez program (np. Coh-Metrix autorstwa McNamary i in. (2014) generuje wyniki dla ponad 100 parametrów), stanowi to jednak w pewnym stopniu efekt przyjętych założeń teoretycznych i definicyjnych czytelności (która wyklucza niektóre formy kohezji). Warunkiem uznania wyrazu za rzadki jest to, że jest to wyraz wielosylabowy (cztery sylaby lub więcej), czyli że jest jednocześnie wyrazem trudnym. Taka implikacja budzi uzasadnioną wątpliwość, bowiem nie wszystkie wyrazy rzadkie są jednocześnie wielosylabowe. Informacje statystyczne dotyczące wyrazów rzadkich są zatem ściśle uzależnione od założenia, które wyrazy uznawane są za trudne, zatem parametr 'wyraz rzadki' niejako częściowo dubluje parametr 'wyraz trudny'. Problem wspomniany wcześniej, mianowicie że nie każdy wyraz wielosylabowy, tzw. „trudny”, jest faktycznie trudny i nie każdy wyraz jedno-, dwu- czy trzysylabowy jest wyrazem łatwym do zrozumienia, nie został całkowicie rozwiązany $\mathrm{w}$ aktualnie dostępnej wersji aplikacji. Jasnopis definiuje bowiem słowo „trudne”, uwzględniając jego charakterystykę frekwencyjną na podstawie listy frekwencyjnej 5000 słów powstałej na bazie pięciu niewielkich słowników (Gruszczyński, Hadryan 2015: 62, Charzyńska 2015: 106), ale redefinicja słów trudnych zapowiadana jest dla kolejnej wersji aplikacji. Ponadto, jak przyznaje autorka przytaczanego studium psycholingwistycznego, grupa respondentów, która miała zweryfikować zmienne psychologiczne mogące mieć wpływ na rozumienie tekstu, okazała się być niereprezentatywna (Charzyńska 2015: 106). Mimo tych niedoskonałości aplikacja Jasnopis jest interesującym (i póki co jedynym) narzędziem dostępnym online, które mierzy zrozumiałość tekstów $\mathrm{w}$ języku polskim w obrębie parametrów porównywalnych do tych dostępnych już w aplikacjach dla języka angielskiego.

Sketch Engine to szeroko znany komercyjny system do zarządzania korpusami powstały w 2003 r. i oferujący szereg testów statystycznych 
i narzędzi do wyszukiwania i analizy słów, a także wiele potencjalnych korpusów referencyjnych, w tym korpusów języka polskiego, również tzw. trzeciej generacji.

Przed dokonaniem analizy ze wszystkich tekstów usunięto metadane, które mogłyby wpłynąć na wyniki i zniekształcić ostateczne wnioski analizy. Usunięto także dane personalne mogące umożliwić zidentyfikowanie pacjenta, zanim przystąpiono do czyszczenia dokumentów z metadanych, zatem oryginalne dokumenty dostępne były tylko jednej autorce niniejszego artykułu. Ponieważ niektóre wskaźniki nie spełniały warunku parametryczności, poniższa analiza, będąca badaniem pilotażowym, sygnalizuje jedynie pewne tendencje, które będzie można zweryfikować na większym korpusie danych. Przy badaniu korelacji za wartość domyślną przyjęto $\mathrm{p}<0,5$, a wartość minimalną efektu wielkości ustalono na 0,1 .

\section{Analiza danych}

Rysunek 1 przedstawia ogólny zarys wyników analizy ilościowej uzyskanej w aplikacji Jasnopis i w programie Sketch Engine. W przeważającej większości parametrów wypisy ze szpitala mają wyższe wartości niż te uzyskane dla opisów badań obrazowych, co - uwzględniając wartości indeksu mglistości (określającego liczbę lat edukacji potrzebnych do zrozumienia tekstu) i indeksu zaproponowanego przez Walerego Pisarka (tzw. indeksu Pisarka) - już wstępnie sygnalizuje możliwość większej trudności w zrozumieniu wypisów, czyli ich mniejszą czytelność. Wynik indeksu mglistości nie jest statystycznie znaczący, jednak zarówno indeks mglistości, jak i indeks Pisarka ujawniają pewną tendencję, którą umocnią inne dane przedstawione $\mathrm{w}$ dalszej części analizy.

Statystycznie istotne różnice między opisami badań obrazowych i wypisami ze szpitala występują w obrębie 2 parametrów: procent wyrazów trudnych i procent rzeczowników trudnych. W wypisach jest nieznacznie więcej wyrazów wielosylabowych $(t=1,91 ;<0,10 ; \mathrm{d}=1,21)$, w szczególności rzeczowników wielosylabowych $(t=2,81 ; \mathrm{d}=1,78)$. Powyższe dane sugerują zatem, że wypisy wykazują mniejszą czytelność niż opisy, a różnicę między nimi można sprowadzić do wyrazów wielosylabowych (głównie rzeczowników), które przeważają w wypisach. 


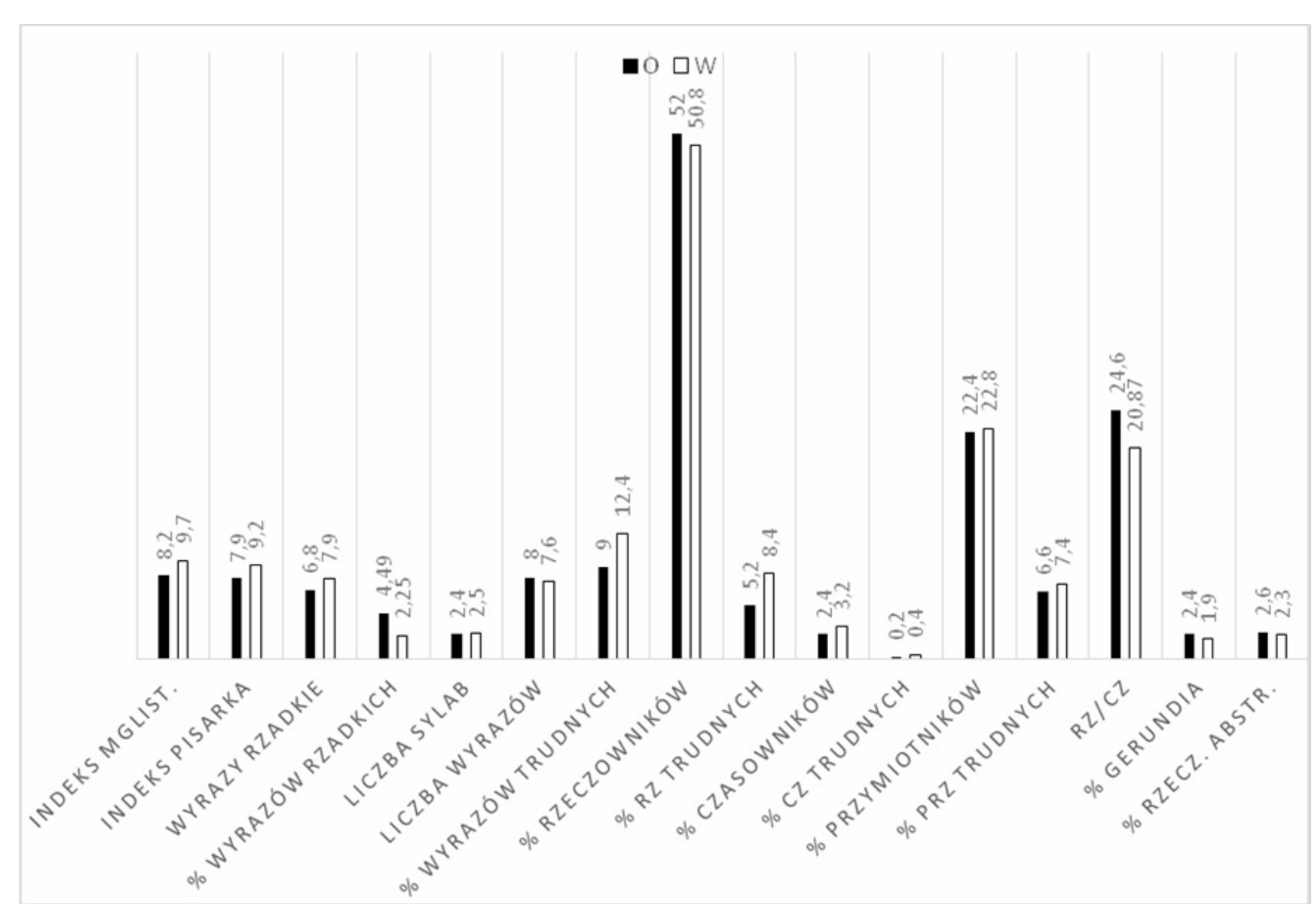

Rysunek 1. Indeksy uwzględnione $\mathrm{w}$ analizie wraz z procentami lub średnimi wyników dla opisów badań obrazowych („O”) i wypisów ze szpitala („W”)

Kolejny parametr uwzględniony w niniejszej analizie to wyrazy rzadkie, czyli takie, które cechują się niską charakterystyką frekwencyjną. W Jasnopisie uznaje się za nie te, których wystąpienia nie przekraczają 5 na 100.000 słów (Gruszczyński, Broda 2015: 7). Wyrazów tych jest więcej w wypisach, co wpływa negatywnie na ich czytelność. Wskaźnik ten jednak silnie koreluje z długością tekstów, dlatego należy go potraktować jako wskazujący jedynie pewne tendencje.

Parametr ściśle związany $\mathrm{z}$ czytelnością $\mathrm{w}$ rozumieniu testów klasycznych to średnia liczba sylab w wyrazie, która okazała się większa w wypisach. Dłuższe wyrazy sugerują większą trudność w ich zrozumieniu, podobnie jak zdania wielowyrazowe, ponieważ wymagają większego wysiłku kognitywnego do ich przetworzenia. Zdania są średnio nieco dłuższe w opisach badań obrazowych, natomiast średnia liczba sylab w wyrazach jest bardzo zbliżona w opisach i wypisach.

Jak wcześniej wspomniano, wyrazy trudne w Jasnopisie to takie, które mają 4 lub więcej sylab (Pisarek 2007: 261, Gąsiorek i in. 2014) oraz które nie znajdują się na liście referencyjnej 5000 słów o najwyższej frekwencji 
(Gruszczyński, Hadryan 2015: 62). Wyrazów trudnych jest ponownie więcej w wypisach ze szpitali niż w opisach badań obrazowych.

Inny wskaźnik uwzględniony $\mathrm{w}$ badaniu to procent rzeczowników i czasowników w tekście (oraz ich logarytmy). Warto zauważyć, że około połowa tekstów zarówno $\mathrm{w}$ przypadku opisów, jak i wypisów składa się $\mathrm{z}$ rzeczowników (z niewielką przewagą $\mathrm{w}$ opisach). Procent rzeczowników trudnych (wielosylabowych) jest wyższy w przypadku wypisów ze szpitali, podobnie jak procent czasowników i przymiotników. Indeks $\mathrm{Rz} / \mathrm{Cz}$, tj. procent rzeczowników względem czasowników jest uważany według niektórych autorów (Gruszczyński, Ogrodniczuk 2015) za wskaźnik trudności tekstu, tzn. im więcej jest rzeczowników, tym tekst jest mniej zrozumiały. Inni autorzy z kolei (Crossley, Skalicky, Dascalu, McNamara, Kyle, 2017: 15) zauważyli odwrotną tendencję, mianowicie że wysoki procent czasowników jest wskaźnikiem dużej trudności tekstu. Opisy badań obrazowych w naszym badaniu zawierają więcej rzeczowników w stosunku do czasowników, co wydaje się popierać tezę Scotta Crossley’a, Kristophera Kyle’a, Danielle McNamary (2017).

Gerundia oraz rzeczowniki abstrakcyjne wyekstrahowano z korpusów za pomocą narzędzi dostępnych w systemie Sketch Engine. Obydwu parametrom przypisuje się zwiększanie trudności tekstu (Gruszczyński, Hadryan 2015: 48). Rzeczowniki konkretne uznawane są za bardziej zrozumiałe, bowiem łatwiej jest je zapamiętać z uwagi na fakt, że w umyśle odbiorcy komunikatu aktywują one pamięć związaną ze zmysłami (percepcją) (Brysbaert, Warriner, Kuperman 2013). Desygnaty rzeczowników konkretnych istnieją w rzeczywistości, można na nie wskazać, wziąć do ręki czy wykonać jakieś czynności za ich pomocą. W naszych danych zarówno gerundia (KBO=2,4\%, KWS=1,9\%), jak i rzeczowniki abstrakcyjne (KBO=2,6\%, KWS=2,3\%) występują częściej w opisach.

Po tym ogólnym przeglądzie wartości poszczególnych indeksów wyłania się wstępnie obraz czytelności przeciwny do oczekiwanych wyników, mianowicie wypisy wykazują mniejszą czytelność niż opisy badań obrazowych. Ponieważ wypisy ze szpitala sporządzane są przez lekarza dla pacjenta i zawierają, oprócz przebiegu leczenia i rozpoznania również zalecenia pohospitalizacyjne (dawkowanie leków, dalsze leczenie, zalecane kolejne wizyty i badania oraz rekomendacje dotyczące wprowadzania zmian żywieniowych, zachowań prozdrowotnych czy zmiany stylu życia), wydaje się, że czytelność takiego tekstu powinna być stosunkowo duża, aby pacjent rozumiał zalecenia lekarza i mógł się dowiedzieć, jakie było rozpoznanie. 
Z tego względu wstępnie założono, że wypisy będą cechowały się większą czytelnością. Z opisanej powyżej analizy wynika jednak, że wypisy ze szpitala są mniej czytelne niż opisy badań obrazowych. W dalszej części artykułu przedstawione zostaną bardziej szczegółowo zauważone tendencje oraz korelacje.

\subsection{Analiza tendencji i korelacji}

Procent rzeczowników $\mathrm{w}$ stosunku do czasowników (Rz/Cz) pozytywnie koreluje z procentem czasowników trudnych $(r=0,89)$, zatem $\mathrm{w}$ wypisach jest nie tylko więcej rzeczowników względem czasowników, ale też jest więcej czasowników trudnych. Czasowniki trudne (według tagsetu dostępnego w SK) w wypisach stanowią 20,7\%, a w opisach $14 \%$ wszystkich czasowników $\mathrm{w}$ danym korpusie. Czasowniki trudne $\mathrm{w}$ opisach to m.in.: obejmować, uwidocznić, odpowiadać, zróżnicować, sugerować, zobrazować, występować, natomiast $\mathrm{w}$ wypisach to np.: konsultować, obserwować, hospitalizować, uzyskiwać, zmodyfikować, utrzymywać, przeprowadzić, odpowiadać, zaczerwienić, gorączkować.

Rzeczowniki trudne $\mathrm{z}$ kolei występują zarówno w opisach (11\% wszystkich rzeczowników w KBO), jak i wypisach (19,7\% wszystkich rzeczowników w KWS). Innymi słowy, w opisach co dziesiąty rzeczownik jest wielosylabowy, a w wypisach co piąty. Jak wynika z przytoczonych poniżej przykładów wyekscerpowanych z badanych korpusów (przy użyciu tagsetu dostępnego w SK), rzeczowniki wielosylabowe zawierają terminy fachowe (które są trudne), jednakże oprócz terminów medycznych są też rzeczowniki ogólnie znane, które z pewnością nie są trudne nawet dla czytelnika niewykształconego (np. pochodzenie, zapalenie, położenie). Rzeczowniki trudne w opisach to np.: gruczolakorak, echogeniczność, torbielakogruczolak, ovariorum, preeklampsja, zapłodnienie, podejrzenie, wodobrzusze, diagnostyka, wykształcenie, wieloródka, intensywność, wypisy $\mathrm{z}$ kolei zawierają takie wyrazy jak np.: hospitalizacja, dolegliwość, znieczulenie, zapalenie, insuflacja, perystaltyka, nasilenie, dolegliwość, kolonoskopia, epikryza, enzymopatia, biotynidazy, cytomegalia, przepuklina, profilaktyka, ceroidolipofuscynoza, tachykardia, powikłanie.

Ponadto rzeczowniki wielosylabowe, które wystąpiły co najmniej 5 razy w korpusie wypisów, mają średnią frekwencję zredukowaną (uwzględniającą liczbę dokumentów względem liczby wystąpień) oscylującą wokół wartości 4 (np. morfologia -3,4; diagnostyka-4,2), natomiast w korpusie opisów wartości te są niższe i oscylują wokół 1,5 (np. podejrzenie - 1,7; wodobrzusze - 1,5; 
wieloródka - 1,3). Rzeczowniki trudne w wypisach są zatem dystrybuowane bardziej równomiernie $\mathrm{w}$ całym korpusie, podczas gdy w korpusie opisów mają tendencję do występowania $\mathrm{w}$ pojedynczym dokumencie, co potwierdza wcześniejszą obserwację, że wypisy wydają się trudniejsze do zrozumienia niż opisy, bowiem rzeczowniki wielosylabowe są $w$ nich raczej normą niż wyjątkiem.

Porównanie procentu rzeczowników, czasowników i przymiotników w stosunku do wszystkich słów w korpusie można dobrze zaobserwować na podstawie indeksów logarytmicznych (parametrów log \%Rz, log $\% \mathrm{Cz}$, $\log \% \operatorname{Prz~i~\% Rz/Cz),~co~ilustrują~poniższe~wykresy~(rys.~2a-d).~Wynika~z~nich,~}$ że w opisach badań obrazowych rzeczowników jest procentowo więcej niż w wypisach, natomiast czasowników jest procentowo więcej w wypisach. Ponieważ ogólny poziom zrozumienia tekstu wydaje się być wyższy w przypadku opisów, można wstępnie założyć, że większa liczba użytych w tekście rzeczowników nie ma dużego wpływu negatywnego na jego czytelność. W opisach istnieje nie tylko tendencja do stosowania większej liczby rzeczowników w stosunku do wszystkich słów w tekście, ale też do ich większej liczby w stosunku do czasowników niż to ma miejsce w przypadku wypisów. Można zatem podejrzewać, że zarówno duża liczba rzeczowników, jak i ich wysoka okurencja w stosunku do czasowników nie mają wpływu na obniżenie klarowności tekstu. Liczba przymiotników względem wszystkich słów w danym korpusie jest ponownie większa w wypisach niż w opisach, co może przyczyniać się do zmniejszenia czytelności tekstów (mając na uwadze indeksy mglistości i Pisarka dla obu korpusów).

Ponadto można też zaobserwować słabą korelację (statystycznie nieznaczącą) między okurencją słów rzadkich a frekwencją rzeczowników trudnych $\left(r_{s}=0,6, p=0,391\right)$, co sugeruje, że w opisach badań obrazowych słowa rzadkie mogą często występować jako rzeczowniki wielosylabowe. 


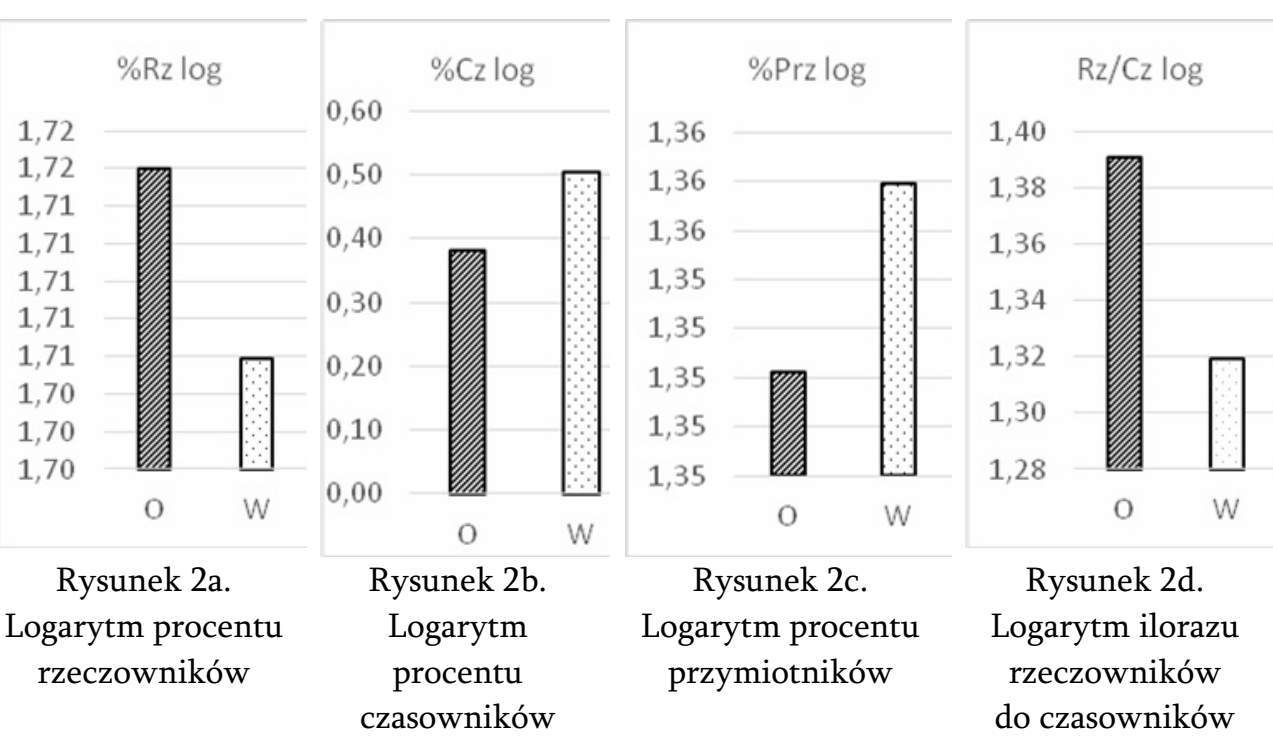

\subsubsection{Rzeczowniki abstrakcyjne}

Za typowe wyznaczniki rzeczowników abstrakcyjnych przyjęto, za Włodzimierzem Gruszczyńskim i Mileną Hadryan (2015: 48), końcówki -ość, cja, -sja. Ponieważ w zastosowanym tagsecie (czyli zbiorze znaczników morfosyntaktycznych, tj. tagów, które opisują części mowy w odniesieniu do tokenów) nie ma specjalnych znaczników dla rzeczowników abstrakcyjnych, ich ekstrakcja przeprowadzona była poprzez automatyczne wyszukiwanie wyrazów (tj. bez analizy ich kontekstów) z zakończeniami wymienionymi powyżej przy zastosowaniu składni języka zapytań wykorzystywanego w SK. Jak już wcześniej wspomniano, rzeczowniki abstrakcyjne są zasadniczo postrzegane jako źródło trudności tekstów (Gruszczyński, Ogrodniczuk 2015: $48,73,105)$, jednak należy zwrócić uwagę na fakt, że nie każdy taki rzeczownik jest trudny w zrozumieniu. Tabela 1 . poniżej przedstawia frekwencje absolutne wystąpień po standaryzacji na milion słów (FS) rzeczowników abstrakcyjnych w korpusie badań obrazowych oraz w korpusie wypisów ze szpitali obliczonych na podstawie korpusu referencyjnego plTenTen12 (Jakubíček i in. 2013). Dane te zostały automatycznie ekstrahowane z korpusu. 
Tabela 1. Frekwencja absolutna rzeczowników abstrakcyjnych po standaryzacji na milion słów

\begin{tabular}{|c|c|c|c|}
\hline $\mathrm{KBO}$ & FS & KWS & FS \\
\hline wysokość $(4 \mathrm{x})$ & 150,62 & ilość $(3 \mathrm{x})$ & 243,82 \\
\hline racja ( r racji $)$ & 132,13 & funkcja & 175,61 \\
\hline wielkość $(4 \mathrm{x})$ & 81,72 & wielkość $(2 \mathrm{x})$ & 81,72 \\
\hline czynność & 74,97 & operacja $(2 \mathrm{x})$ & 73,91 \\
\hline operacja & 73,91 & obecność $(2 \mathrm{x})$ & 73,39 \\
\hline obecność & 73,39 & głębokość & 62,07 \\
\hline długość (3x) & 72,65 & rejestracja $(2 \mathrm{x})$ & 42,16 \\
\hline Lokalizacja & 50,53 & konsultacja & 33,1 \\
\hline kość & 37,43 & interwencja & 27,44 \\
\hline konsultacja & 33,1 & tendencja & 26,97 \\
\hline dolegliwość & 20,41 & odporność & 23,47 \\
\hline intensywność & 7,85 & kontynuacja & 20,66 \\
\hline ruchomość & 1,96 & dolegliwość $(5 \mathrm{x})$ & 20,41 \\
\hline echogeniczność $(2 \mathrm{x})$ & 0,05 & redukcja & 18,67 \\
\hline rodność & 0,01 & proporcja & 16,48 \\
\hline \multirow[t]{16}{*}{ przezierność } & 0,24 & stabilizacja & 10,88 \\
\hline & & kwalifikacja & 8,56 \\
\hline & & niewydolność & 5,8 \\
\hline & & destrukcja & 2,98 \\
\hline & & wydolność & 2,67 \\
\hline & & hospitalizacja & 2,29 \\
\hline & & senność & 2,2 \\
\hline & & niedoczynność & 2,15 \\
\hline & & detekcja & 1,92 \\
\hline & & niedokrwistość & 1,81 \\
\hline & & inhalacja & 1,44 \\
\hline & & implantacja $(2 \mathrm{x})$ & 0,9 \\
\hline & & inwersja & 0,59 \\
\hline & & bladość & 0,51 \\
\hline & & spoistość & 0,42 \\
\hline & & $\begin{array}{l}\text { niedomykalność } \\
\text { (zastawki mitralnej) }\end{array}$ & 0,26 \\
\hline
\end{tabular}

Procentowo w tekstach opisów więcej jest rzeczowników abstrakcyjnych niż w wypisach. Trudność w rozumieniu tych wyrazów nie zawsze jest jednak znacząca, co wynika nie tyle $\mathrm{z}$ liczby sylab, które zawierają, ile $\mathrm{z}$ ich charakterystyki frekwencyjnej. Wyrazy takie jak ilość, czynność czy obecność 
są łatwe do zrozumienia. Kolejną kwestią, którą trzeba rozważyć, jest rozkład wyrazów trudnych w danym korpusie. Wyraz trudny, jakim jest echogeniczność, wystąpił $\mathrm{w}$ dwóch dokumentach, a np. rodność czy przezierność tylko w pojedynczych tekstach. Ponadto wyraz bladość $(\mathrm{F}=0,51)$, który ma niską frekwencję absolutną, wydaje się być bardziej zrozumiały dla osoby słabo wykształconej niż na przykład hospitalizacja, z uwagi na fakt, że jest on derywowany od przymiotnika blady ( $\mathrm{F}=10,27)$. Hospitalizacja z kolei jest wyrazem pochodzenia obcego, zapożyczona prawdopodobnie $\mathrm{z}$ angielskiego hospital (szpital) lub łacińskiego hospitium. Nie jest zatem zachowana $\mathrm{w}$ języku polskim spójność nazewnicza między określeniem okresu przebywania pacjenta w szpitalu czy samego aktu umieszczenia go tamże (hospitalizacja), a nazwą budynku, którego opisany stan lub czynność dotyczą (szpital). Z tego powodu hospitalizacja może być niezrozumiała dla czytelnika. Z powyższych rozważań wynika, że nie tylko klasyczne testy na czytelność nie spełniają swojej roli, ale i testy oparte na wskaźnikach leksykalnych mogą nie być wystarczająco wiarygodne, o ile biorą one pod uwagę jedynie pojedyncze aspekty leksemów. Wpływ rzeczowników abstrakcyjnych na zrozumiałość tekstu powinien być rozważany przy uwzględnieniu nie tylko ich sensów (nie)abstrakcyjnych i liczby sylab, które zawierają, ale też innych aspektów, w szczególności ich frekwencji i dystrybucji oraz spójności nazewniczej.

Nie bez znaczenia jest metoda ekstrakcji rzeczowników abstrakcyjnych. Ponieważ ekstrakcja danych z korpusów zachodzi automatycznie, słowo układ, mimo iż generalnie jest rzeczownikiem abstrakcyjnym, nie zostało zidentyfikowane $\mathrm{w}$ analizie jako rzeczownik abstrakcyjny, dlatego że nie kończy się na -ość czy -s/cja, natomiast słowo kość pojawiło się w kategorii rzeczowników abstrakcyjnych, co jest kontrowersyjne, bowiem wydaje się, że zdecydowanie częściej używane jest w sensie konkretnym (w abstrakcyjnym może być użyte na przykład w zwrocie dać $w$ kość). Ponadto -ość nie jest w przypadku wyrazu kość końcówką. Trzeba pamiętać, że w języku zapytań w SK nie ma możliwości automatycznej ekstrakcji rzeczowników abstrakcyjnych (stąd brak rzeczownika układ). Język zapytań nie pozwala też odróżnić wyrazy, do których tematu dodana jest końcówka -ość od tych, które po prostu kończą się na -ość, stąd pojawienie się wyrazu kość w wyekstrahowanych danych.

Niezwykle istotny w analizie rzeczowników abstrakcyjnych jest kontekst (a konkretnie kotekst) oraz sprawdzenie, czy dany wyraz nie jest elementem jednostki wielowyrazowej albo bigramu (ogólnie rzecz biorąc n-gramu). Warto przy okazji zauważyć, że słowo układ może mieć znaczenie abstrakcyjne lub konkretne. W jednostce wielowyrazowej układ kielichowo-miedniczkowy, 
która wystąpiła w analizowanym korpusie, ma sens konkretny, dotyczy bowiem konkretnego, fizycznego miejsca i elementów, które współtworzą (wraz z moczowodami) górne drogi moczowe w ciele określonego człowieka. Pojawia się zatem kolejny problem metodologiczny, tj. możliwość zmiany sensu abstrakcyjnego na konkretny pod wpływem kontekstu. Inną kwestią, którą należałoby wziąć pod uwagę podczas analizy języka medycznego, jest uwzględnienie frekwencji nie tylko pojedynczych wyrazów w korpusie, ale też frekwencji n-gramów, a w szczególności tzw. wartości C, która odnosi się do jednostek zagnieżdżonych (zob. Frantzi i in. 2000), zwłaszcza tych n-gramów, które są terminami fachowymi. Nie bez znaczenia jest też fakt, że nie wszystkie jednostki wielowyrazowe zawierające rzeczownik w badanych korpusach to skomplikowane i niezrozumiałe medyczne terminy fachowe, np. utrata masy ciała czy stan ogólny średni to n-gramy zawierające rzeczowniki abstrakcyjne, jednak są one łatwe do zrozumienia, mimo iż na przykład rzeczownik utrata $(\mathrm{FS}=42,42)$ ma dziesięciokrotnie niższą frekwencję absolutną w języku ogólnym, niż $\operatorname{stan}(\mathrm{FS}=459,12)$.

\subsubsection{Gerundia}

W polskim językoznawstwie korpusowym problem odróżnienia „odsłowników od rzeczowników nie został satysfakcjonujaco rozwiązany", dlatego przyjęto kryteria, które mają jedynie przemawiać za interpretacją odsłownikową (gerundium nazywane jest też odsłownikiem), to jest: występowanie określonych argumentów po gerundium, np. zaimków (pomaganie mu), okoliczników czasu (bieganie 2 godziny), przysłówków (robienie czegoś szybko) lub agensa po przyimku przez (przejęcie władzy przez rebeliantów) (Szałkiewicz, Przepiórkowski 2012: 76). W niniejszym badaniu gerundia wyekstrahowano z korpusów automatycznie poprzez polecenie wyszukania wyrazów $\mathrm{z}$ anotacją morfosyntaktyczną rzeczownika odczasownikowego (tagset używany w Narodowym Korpusie Języka Polskiego). Wymienione w tabeli 2 gerundia potencjalnie mogą wyrażać zarówno pojęcia abstrakcyjne, jak i konkretne.

Rozróżnienie, czy dany wyraz ilustruje znaczenie abstrakcyjne czy konkretne, nie zawsze jest jednak łatwym zadaniem. W zdaniu Umiarkowane pływanie jest zdrową formą ruchu. wyraz pływanie można zinterpretować jako rzeczownik abstrakcyjny, ale w zdaniu $W$ lodówce jest twoje jedzenie na dziś. wyraz jedzenie użyte jest w sensie konkretnym. Kwalifikacja ta zależy zatem w dużej mierze od kontekstu. Na marginesie warto wspomnieć, że istnieją wyrazy, w których odróżnienie to jest zwykle łatwiejsze z uwagi na dwie różne 
formy, które mogą one przyjąć, np. ocena (rzeczownik abstrakcyjny pochodzący od czasownika oceniać) vs. ocenianie (gerundium), weryfikacja vs. weryfikowanie, śpiew vs. śpiewanie, chód vs. chodzenie, bieg vs. bieganie itp. W tych przypadkach wydaje się, że przytoczone powyżej cztery kryteria nie są niezbędne dla odróżnienia gerundium od rzeczownika, który nie jest odsłowny.

Tabela 2. Frekwencja absolutna gerundiów po standaryzacji na milion słów

\begin{tabular}{|c|c|c|c|}
\hline $\mathrm{KBO}$ & FS & KWS & FS \\
\hline badanie $(3 \mathrm{x})$ & 293,36 & badanie $(4 \mathrm{x})$ & 293,36 \\
\hline $\begin{array}{l}\text { zajęcie (przestrzeni } \\
\text { nadoponowej) }\end{array}$ & 107,7 & wykonanie $(3 \mathrm{x})$ & 90,92 \\
\hline leczenie $(2 \mathrm{x})$ & 83,06 & leczenie $(5 \mathrm{x})$ & 83,06 \\
\hline ustawienie & 39,76 & wydanie & 54,99 \\
\hline pochodzenie & 37,58 & uszkodzenia $(2 \mathrm{x})$ & 30,65 \\
\hline położenie & 35,58 & funkcjonowanie & 27,43 \\
\hline podanie $(4 \mathrm{x})$ & 17,23 & uzyskanie & 19,73 \\
\hline podejrzenie & 14,95 & opóźnienie & 19,32 \\
\hline wzmocnienie $(2 \mathrm{x})$ & 13,88 & zmniejszenie & 18,73 \\
\hline palenie & 13,71 & wzmocnienie & 13,88 \\
\hline rozpoznanie $(3 \mathrm{x})$ & 12,18 & złamanie & 8,74 \\
\hline nadciśnienie & 7,12 & podawanie & 6,22 \\
\hline rozważenie & 1,22 & pobranie & 5,42 \\
\hline \multirow[t]{10}{*}{ zobrazowanie } & 0,5 & poszerzenie & 5,27 \\
\hline & & monitorowanie & 4,9 \\
\hline & & zahamowanie & 2,42 \\
\hline & & zwężenie (2x) & 1,61 \\
\hline & & porażenie & 1,61 \\
\hline & & $\begin{array}{l}\text { zaciągnięcie } \\
\text { (międzyżebrzy) }\end{array}$ & 1,14 \\
\hline & & uwięźnięcie & 0,6 \\
\hline & & szarpnięcie & 0,46 \\
\hline & & zwapnienie & 0,24 \\
\hline & & $\begin{array}{l}\text { furczenia (nad polami } \\
\text { płucnymi liczne świsty } \\
\text { i furczenia) }\end{array}$ & 0,01 \\
\hline
\end{tabular}

Gruszczyński i Hadryan (2015: 48) utrzymują, że wyższa liczba okurencji gerundiów niekorzystnie wpływa na zrozumiałość tekstu, a usunięcie rzeczowników odsłownych z tekstu może zwiększyć jego czytelność nawet trzykrotnie. Trzeba jednak pamiętać, że autorzy ci traktują gerundia jako 
rzeczowniki abstrakcyjne. Z analizy kontekstów w badanych korpusach można wywnioskować, że gerundia są w przeważającej większości pojęciami nieabstrakcyjnymi, dotyczą bowiem opisu konkretnych przypadków chorobowych. Takie wyrazy nie wydają się trudne w odbiorze. Większość z nich jest ogólnie zrozumiała, choć w korpusie WS jest kilka słów, które mogą być mniej zrozumiałe lub nieczytelne dla pacjenta w kontekście opisu stanu chorobowego (np. uwięźnięcie, zaciągnięcie czy furczenie).

Podsumowując, można powiedzieć, że na podstawie analizy użycia gerundiów w naszych korpusach nie można stanowczo stwierdzić, że rzeczownik odsłowny jest źródłem trudności w zrozumieniu tekstu, bowiem występujące $\mathrm{w}$ nich gerundia są wyrazami stosunkowo często używanymi w języku codziennym i dotyczą raczej użyć nieabstrakcyjnych. Wynika z tego, że - podobnie jak w przypadku rzeczowników abstrakcyjnych - przy ocenie czytelności tekstu sam parametr długości wyrazu nie jest aż tak istotny jak jego charakterystyka frekwencyjna i sens czy kontekst, w którym się pojawia. Niewątpliwie jednak fakt, że więcej przypadków użycia gerundiów zanotowano $\mathrm{w}$ wypisach ze szpitali oraz że niektóre $\mathrm{z}$ nich są raczej mało znane, może przyczyniać się do obniżenia czytelności tekstu.

Problemy metodologiczne dotyczą jednak nie tylko kwestii natury językoznawczej, np. opisanych powyżej klasyfikacji leksemów jako abstrakcyjnych czy konkretnych, ale też aspektów natury bardziej „technicznej”, tj. związanych z przyjętą metodą automatycznej ekstrakcji danych. Identyfikacja rzeczowników odsłownych omówionych powyżej, jak już wspomniano, przebiegała na podstawie znacznika morfosyntaktycznego gerundium stosowanego w NKJP. Warto jednak podkreślić, że automatyczne wyszukiwanie gerundiów za pomocą składni języka zapytań zawierającej końcówki gerundium (-nie, - cie) dało nieco odmienne wyniki, które były mniej dokładne. Pozyskane $\mathrm{w}$ ten sposób wyrazy różniły się od tych wyekstrahowanych za pomocą tagsetu używanego w NKJP ilościowo (w przypadku wyszukiwania poprzez końcówki było ich znacznie mniej) i jakościowo (np. ujście, położenie, wykształcenie itp. nie pojawiły się w wyszukiwaniu poprzez tag gerundium, wyrazy te oznaczono w NKJP tagiem rzeczownika). Różnice te były znaczące, dlatego warto pamiętać, że przyjęta metoda ekstrakcji danych może mieć istotny wpływ na wynik procesu ich wydobywania z korpusu, a tym samym na interpretację wyników. Trzeba też pamiętać, że automatyczna anotacja tagów nie jest w $100 \%$ nieomylna. Dla języka angielskiego poprawność tagerów sięga 97\% (Kobyliński 2013), dla języka polskiego jedynie ok. 93\% w NKJP (Szałkiewicz, Przepiórkowski 2012). Łukasz Kobyliński i Witold Kieraś (2016) podają jednak 
jedynie 91\% w odniesieniu do ok. milionowego korpusu treningowego utworzonego na potrzeby NKJP. Jest to niska wartość dla języka fleksyjnego w porównaniu do innych słowiańskich języków fleksyjnych, np. czeskiego czy słoweńskiego (Kobyliński, Kieraś 2016). Najnowsze tagery proponują rozwiązania, które osiągają dokładność rzędu 94,5\% (Kobylińśki, Wasiluk, Wojdyga 2018), nie są one jednak zaimplementowane do tagera NKJP dostępnego w SK, ponadto jest to nadal dość znaczący margines błędu.

$\mathrm{Na}$ kwestię problemów $\mathrm{z}$ poprawnością automatycznej anotacji gerundiów w korpusie języka polskiego zwrócił już uwagę Kobyliński (2013), który zauważył, że wyraz głosowanie był oznaczony albo jako gerundium albo rzeczownik. W naszych danych tagset oparty na klasyfikacji NKJP oznaczył (drobne) zwapnienie jako gerundium, ale znieczulenie (ogólne) już nie, mimo iż oba rzeczowniki pochodzą od czasowników i są doprecyzowane przymiotnikami. Teoretycznie rozbieżność ta mogłaby wynikać z analizy kontekstu, w wyniku czego przydawka klasyfikująca (wyrażająca stałość) zdecydowałaby o przypisaniu wyrazu do rzeczowników, a przydawka charakteryzująca (wyrażająca temporalność) do klasy gerundium. Tagset NKJP nie posiada jednak oddzielnych tagów takiej anotacji morfosyntaktycznej fleksemów przymiotnikowych, zatem mogła ona wynikać z marginesu błędu poprawności tagera morfoskładniowego zastosowanego w NKJP.

\section{Dyskusja i wnioski}

Mimo stosunkowo niewielkiej liczby analizowanych danych i ograniczeń metodologicznych można zauważyć pewne tendencje i cechy analizowanych tekstów. Różnice statystycznie znaczące między opisami i wypisami zaobserwowano $\mathrm{w}$ obrębie procentu wyrazów trudnych oraz procentu rzeczowników trudnych. W wypisach zidentyfikowano wyższe wartości dla obu wskaźników. Ponadto w wypisach ze szpitali rzeczowniki wielosylabowe mają bardziej równomierny rozkład w korpusie. Nie zaobserwowano natomiast, aby rzeczowniki odsłowne miały wpływ na trudność tekstu, w większości są to bowiem wyrazy ogólnie znane, tj. o wysokiej frekwencji użycia. W wypisach liczniej niż w opisach występują czasowniki i przymiotniki. Okurencja czasowników wielosylabowych jest też w nich wyższa. Rzeczowniki abstrakcyjne oraz gerundia nieznacznie częściej występują $\mathrm{w}$ opisach. Rzeczowniki stanowią około połowy wyrazów w tekście, zarówno w opisach, jak i w wypisach, jednak w opisach, które wydają się być bardziej klarowne, 
jest ich więcej, zatem ich wysoka liczba w tekście wskazuje na tendencję do zwiększenia jego zrozumiałości.

Należy wspomnieć, że podczas analizy wyników badań pojawił się szereg problemów natury metodologicznej. Niektóre kategorie okazały się niejednoznaczne (np. sens abstrakcyjny vs. konkretny) i zależne od kontekstu, a przyjęta metoda automatycznej ekstrakcji danych okazała się mieć istotne znaczenie dla wyników analizy. Nie bez znaczenia jest też anotacja morfosyntaktyczna oraz stopień jej poprawności. Ponadto leksykalne wykładniki trudności tekstu wykorzystane w niniejszym studium nie powinny być analizowane $\mathrm{w}$ izolacji, tylko $\mathrm{w}$ powiązaniu $\mathrm{z}$ szeregiem innych parametrów. Na przykład sam wskaźnik rzeczownik abstrakcyjny może dać mylne wyniki, jeśli nie uwzględni się równocześnie charakterystyki frekwencyjnej danego rzeczownika, kontekstu, w którym występuje (np. funkcji przydawek w związkach atrybutywnych czy sensu abstrakcyjnego/konkretnego), jego dystrybucji w korpusie czy spójności nazewniczej. Obciążona błędem jest też unigramowa analiza morfoskładniowa, dlatego w analizie należy uwzględnić różne poziomy składniowe.

Patrząc na uzyskane dane w szerszym kontekście, należy też zauważyć, że ogólnie rzecz biorąc, rzeczowników w opisach (jak również w wypisach), jest bardzo dużo. Dla porównania procentowy stosunek rzeczowników do czasowników w ulotkach leków wynosi ok. 2,5, co oznacza, że około 2,5 rzeczownika przypada na jeden czasownik (Bączkowska 2020a), tymczasem w opisach niemal aż 25 rzeczowników, a w wypisach prawie 21 rzeczowników przypada na jeden czasownik, tj. około dziesięć razy więcej. Zarówno wypisy, jak i opisy mają indeks mglistości ok. 9, a ulotki we wspomnianym badaniu ok. 7,5. Ogólna tendencja do większej trudności tekstu wraz ze zwiększającą się liczbą rzeczowników oraz zmniejszającą się liczbą czasowników, którą zauważyła Charzyńska (2015: 105), potwierdza się w analizowanych danych jednak częściowo, bowiem to w opisach, które mają większą czytelność, znajduje się jednocześnie więcej rzeczowników. Trzeba jednak pamiętać, że tendencję tę zaobserwowano $\mathrm{w}$ badaniu pilotażowym, tj. na małej liczbie tekstów, dlatego wymaga ona walidacji przy użyciu większych korpusów danych. Ponadto analizie poddano teksty specjalistyczne, medyczne, w których występuje szczególnie dużo terminów fachowych.

Powyższe obserwacje i wnioski pozwalają zdać sobie sprawę z wagi, jaką należy przypisać czytelności tekstu, a tym samym zrozumieniu informacji $\mathrm{w}$ nim zawartych - czyli warunkowi tak naprawdę podstawowemu dla adekwatnego i dobrego jakościowego tłumaczenia. Przedstawiona w artykule 
analiza przybliża pojęcie, zastosowanie i dane statystyczne dotyczące czytelności na omawianych przykładach tekstów medycznych obfitujących $\mathrm{w}$ terminy specjalistyczne, których użycie $\mathrm{z}$ zasady wpływa na poziom zrozumienia tekstu. Pewnym ograniczeniem badania mogą być nie tylko struktury powierzchniowe (jak leksyka czy składnia), ale również takie determinanty kontekstu jak czynniki kulturowe czy tekstologiczne, które również wpływają na rozumienie tekstu przez tłumacza. U tłumacza z pewnością występuje przyjęty a priori wyższy poziom rozumienia tekstu niż u pacjenta (laika). Należy również wziąć pod uwagę fakt, że zrozumienie tekstu przyjmuje postać niejako subiektywnej interpretacji przez odbiorcę znaczenia zawartego w przekazie, a zatem tłumacz buduje $\mathrm{w}$ procesie rozumienia jego własną, indywidualną wersję, która jest pochodną również takiego czynnika jak czytelność.

Rozumienie i przekład tekstów naukowych - w tym przypadku medycznych - jest kwestią trudną i złożoną, bowiem wymaga od tłumacza wiedzy specjalistycznej oraz umiejętności czytania i rozumienia tekstów z danej dziedziny. Celem przekładu w tej sytuacji jest więc przybliżenie odbiorcy (który jest specjalistą lub laikiem) tekstu w sposób wykraczający poza transfer znaczenia na poziomie wyłącznie leksykalno-syntaktycznym. Z uwagi na znaczenie przekładu tekstów medycznych dla ich potencjalnych użytkowników i potencjalnych celów niezwykle istotna jest ich czytelność prowadząca do zrozumienia ich treści, na co uwagę zwrócili już niemieccy teoretycy przekładu kilka lat temu (Maksymski, Gutermuth, Hansen-Schirra 2015). Biorąc pod uwagę rosnącą $\mathrm{w}$ tempie wykładniczym liczbę tekstów, których tłumaczenie służy różnym grupom użytkowników, adekwatne tłumaczenie tekstów medycznych jest niezwykle ważne. Istotny niedosyt prac badawczych w tej dziedzinie stanowi asumpt do podjęcia dalszej debaty. Mamy nadzieję, że powyższy artykuł będzie do niej przyczynkiem.

\section{BIBLIOGRAFIA}

Bartmiński, J., Niebrzegowska-Bartmińska, S. (2012). Tekstologia. Warszawa.

Bączkowska, A. (2019). Readability and lexical sophistication of colon cancer websites a corpus-assisted assessment of online educational materials for patients. Forum Filologiczne Ateneum, 7(1), 9 -25. https://doi.org/10.36575/2353-2912/1(7)2019.009

Bączkowska, A. (2020a). Zrozumiałość przekładu tekstów użytkowych. Automatyczna analiza tłumaczeń ulotek leków na cukrzycę, Studia Slavica, XXIV(1), 95-122.

Bączkowska, A. (2020b). Automatyczna analiza dyskursu medycznego. [W:] K. Pawlak-Osińska, M. Śniegocki, M. Szpinda (red.) Nowoczesne trendy diagnostyki i terapii. Toruń, 551-567.

Bailin, A. \& Grafstein, A. (2016). Readability: Text and context. Basingstoke. 
Bazerman, C. (1994). Systems of genres and the enactment of social intentions. [w:] A. Freedman, P. Medway (red.), Genre and the New Rhetoric. London: Taylor \& Francis, 79-101.

Bhatia, V. K. (2002). Applied genre analysis. A multi-perspective model. Ibérica: Revista de la Asociación Europea de Lenguas para Fines Específicos, t. 4, 3-19.

Boniecka, B. (1994). Tekst w kontekście (problemy metodologiczne), Polonica, 16, 43-67.

Broda, B., Maziarz, M., Piekot, T. \& Radziszewski A. (2010). Trudność tekstów o funduszach europejskich w świetle miar statystycznych, Rozprawy Komisji Językowej, 37, 23-40.

Brysbaert, M., Warriner, A. B. \& Kuperman, V. (2013). Concretness ratings for 40 thousand generally known English word lemmas, Behavior Research Methods, 46, 904-911.

Bublitz, W. (2011). Cohesion and coherence. [W:] J. Zienkowski, J.-O. Östman, J. Versschueren (red). Discursive pragmatics. Amsterdam, 37-49.

Charzyńska, E. (2015). Badania ankietowe. [W:] W. Gruszczyński, M. Ogrodniczuk (red.), Jasnopis, czyli mierzenie zrozumiałości polskich tekstów użytkowych. Warszawa, 77-108.

Charzyńska, E., Dębowski Ł., Gruszczyński, W. \& Hadryan, M. (2015). Historia badań nad zrozumiałością tekstu. [w:] W. Gruszczyński, M. Ogrodniczuk (red.). Jasnopis, czyli mierzenie zrozumiałości polskich tekstów użytkowych. Warszawa, 11-38.

Clerehan, R., Buchbinder, R. \& Moodie, J. (2005). A linguistic framework for assessing the quality of written patient information: its use in assessing methotrexate information for rheumatoid arthritis, Health Education Research, 20, 334-344.

Crossley, S. A., Kyle, K. \& McNamara, D. S. (2016). The tool for the automatic analysis of text cohesion (TAACO). Automatic assessment of local, global, and text cohesion, Behavior Research Methods, 48(4), 1227-1237.

Crossley, S. A., Skalicky, S., Dascalu, M., McNamara, D. S. \& Kyle, K. (2017). Predicting text comprehension, processing, and familiarity in adult readers: New approaches to readability formulas. Discourse Processes, 54(5-6), 340-359.

Crossley, S. A., Skalicky, S. \& Dascalu, M. (2019). Moving beyond classic readability formulas. New methods and new models, Journal of Research in Reading, 42(3-4), 541-561.

Davidson, A. \& Kantor, R. N. (1982). On the failure of readability formulas to define readable texts. A case study from adaptations. Reading Research Quarterly, 17(2), 187-209.

Doak, C. C., Doak, L. G. \& Root J. H. (1996). Teaching patients with low literacy skills. Philadelphia: J.B. Lippincott Company.

Dobrzyńska, T. (2009). Pojęcie tekstu. Tekst - całościowy komunikat. [W:] Z. Bilut-Homplewicz, W. Czachura, M. Smykała (red.) Lingwistyka tekstu w Polsce $i$ w Niemczech. Pojęcia, problemy, perspektywy. (ss. 35-44). Wrocław.

Dobbs, T., Neal, G., Hutchings, H. A., Whitaker, I. S. \& Milton J. (2017). The readability of online patient resources for skin cancer treatment. Oncology and Therapy, 5, 149-160.

Ezpeleta-Piorno, P. (2012). An example of genre shift in the medicinal product information genre system. Linguistica Antverpiensia, 11, 139-159.

Frantzi, K., Ananiadou, S., Mima, H. \& Tsujii J. (2000). The C-value/NC-value method of automatic recognition for multi-word terms. [W:] C. Nikolaou, C. Stephanidis (red.). Research and advanced technology for digital libraries, Berlin, 585-604.

Gajda, S. (1982). Podstawy badań stylistycznych nad językiem naukowym. Warszawa.

Garner, M., Ning Z. \& Francis J., 2012, A framework for the evaluation of patient information leaflets. Health Expectations, 15(3), 283-294.

Gąsiorek, K., Hącia, A., Kłosińska, K., Krzyżyk, D., Nocoń J. \& Synowiec, H. (2014). Kryteria oceny podręcznika szkolnego w aspekcie językowym. https://www.gov.pl/web/edukacja/ 
wytyczne-edytorskie-i-jezykowe-do-opracowania-podrecznikow-oraz-wytyczne-douniwersalnego-projektowania-graficznego-podrecznikow (dostęp: 30.11.2019).

Gonzalez Darriba, P. (2018). English to Spanish translated medical forms. A descriptive genrebased corpus study. Translation \& Interpreting, 10, 2, 122-141.

Grewal, P. \& Alagaratnam, S. (2013). The quality and readability of colorectal cancer information on the internet. International Journal of Surgery, 11(5), 410-413.

Gruszczyński, W. \& Broda, B. (2015). Wprowadzenie. [W:] W. Gruszczyński, M. Ogrodniczuk (red.). Jasnopis czyli mierzenie zrozumiałości polskich tekstów użytkowych. Warszawa, 1-9.

Gruszczyński, W. \& Hadryan, M. (2015). Cechy tekstu trudnego. [W:] W. Gruszczyński, M. Ogrodniczuk (red.). Jasnopis czyli mierzenie zrozumiałości polskich tekstów użytkowych. Warszawa, 39-75.

Gruszczyński, W. \& Ogrodniczuk, M. (red.) (2015). Jasnopis czyli mierzenie zrozumiałości polskich tekstów użytkowych. Warszawa.

Halliday, M. A. \& Hasan, R. (1976). Cohesion in English. London.

Huang, G., Fang, C. H., Agarwal, N., Bhagat N., Eloy J. A. \& Langer P. D. (2015). Assessment of online patient materials from major ophthalmologic associations, JAMA Ophthalmology, 133(4), 449-454.

Jakubíček, M., Kilgarriff, A., Kovář, V., Rychlý, P. \& Suchomel, V. (2013). The Ten Ten corpus family. [w:] 7th International Corpus Linguistics Conference CL 2013, Lancaster, 125-127.

Kandula, S. \& Zeng-Treitler, Q. (2008). Creating a gold standard for the readability measurement of health texts. AMIA Annual Symposium Proceedings Archive. 2008, 353-357.

Klare, G. R. (1963). The measurement of readability. Iowa.

Kobyliński, Ł. (2013). Improving the accuracy of Polish POS tagging by using voting ensembles. [w:] Z. Vetulani (red.). Proceedings of the $6^{\text {th }}$ Language and Technology Conference. Human Language Technologies as a Challenge for Computer Science and Linguistics. Poznań, 453-456.

Kobyliński, Ł. \& Kieraś W. (2016). Part of speech tagging for Polish. State of the art and future perspectives, [w:] Proceedings of the 17th International Conference on Intelligent Task Processing and Computational Linguistics._http://nlp.ipipan.waw.pl/Bib/kob:kie:16.pdf (dostęp: 16.04.2020).

Kobyliński, Ł., Wasiluk, M. \& Wojdyga, G. (2018). Improving part-of-speech tagging by meta learning, [w:] P. Sojka, A. Horák, I. Kopček, K. Pala (red.) Text, speech and dialogue. Cham, 144-152.

Kościałkowska-Okońska, E. (2017). Tłumacz wobec wyzwań komunikacyjnych. Język tekstów medycznych a oczekiwania odbiorcy. [W:] A. Knapik, A. Misior-Mroczkowska, P. Chruszczewski, W. Chłopicki (red.), Język i komunikacja - Style komunikacyjne (ss. 157-166). t. 39, Kraków: Tertium.

Kościałkowska-Okońska, E. (2019). Translating patient information leaflets. Expectations of users and the realisty. [W:] W. Karwacka (red.), Towards understanding medical translation and interpreting (ss. 137-159). Gdańsk: Wydawnictwo Uniwersytetu Gdańskiego.

Mamet, P. (2002). Kampania Plain English a angielski język specjalistyczny. [W:] J. Arabski (red.). Z problematyki języków specjalistycznych. Katowice, 21-34.

McNamara, D. S., Kintsch, E., Songer, N. B. \& Kintsch W. (1996). Are good texts always better? Interactions of text coherence, background knowledge, and levels of understanding in learning from text. Cognition and Instruction, 14, 1-43. 
McNamara, D. S., Graesser, A. C., McCarthy, P. M. \& Cai, Z. (2014). Automated evaluation of text and discourse with Coh-Metrix. Cambridge.

Maksymski, K., Gutermuth, S. \& Hansen-Schirra, S. (red.) (2015). Translation and comprehensibility. Berlin.

Montalt, V. \& González Davies, M. (2007). Medical translation step by step. Learning by drafting. Manchester: St Jerome Publishing.

Mosenthal, P. \& Kirsch, I. (1998). A new measure of assessing document complexity. The PMOSE/IKIRSCH document readability formula. Journal of Adolescent \& Adult Literacy, 8, 638-657.

Nielson-Bohlman, L., Panzer, A. \& Kindig, D. (2004). Health literacy. A prescription to end confusion. Washington.

Osborne, H. (2004). Health literacy from A To Z. Practical ways to communicate your health. London.

Pieńkos, J. (2003). Podstawy przekładoznawstwa. Od teorii do praktyki. Kraków: Zakamycze.

Pisarek, W. (2007). O mediach i języku. Kraków.

Szałkiewicz, Ł. \& Przepiórkowki, A. (2012). Anotacja morfoskładniowa. [W:] A. Przepiórkowski, M. Bańko, R. L. Górski, B. Lewandowska-Tomaszczyk (red.) Narodowy Korpus Języka Polskiego, Warszawa, 59-96.

Toury, G. (1995). Descriptive Translation Studies and beyond. Amsterdam: John Benjamins.

USDDH (2010). U.S. Department of Health and Human Services. Simply put: a guide for creating easy-to-understand materials, Atlanta, G.A.

van Dijk, T. A. (2008). Text and context. Nowy Jork.

Wang, L. W., Miller M. J., Schmitt R. R. \& Wen F. K. (2012). Assessing readability formula differences with written health information materials. Application, results, and recommendations. Research in Social \& Administrative Pharmacy, 9, 5, 503-516.

Wojtak, M. (2005). Genologia tekstów użytkowych. [W:] M. Czermińska (red.), Polonistyka w przebudowie (ss.132-148). t. 1. Kraków: Universitas.

Wolfer, S. (2015). Comprehension and comprehensibility. [W:], K. Maksymski, S. Gutermuth, S. Hansen-Schirra (red.). Translation and comprehensibility. Berlin, 33-52.

Zarzeczny, G. \& Piekot, T. (2017). Przystępność tekstów urzędowych w internecie. Wrocław. 
